\title{
Sampling methods of microplastics in freshwater and seawater envionment
}

\author{
Amnan Haris*, Hadiyanto Hadiyanto, Fuad Muhammad \\ Master of Environmental Sciences, Diponegoro University, Semarang 50241, Indonesia
}

\begin{abstract}
Microplastic had been contaminating freshwater ecosystem. But, our knowledge to identify kind of microplastics are still limited. Microplastic research methods in both water and sediment are generally divided into several stages: sampling, sample purification and sample identification. Samples can come from water or sediment. This journal provides several microplastic sampling methods to choose from, along with their advantages and disadvantages. Until a pure microplastic sample is obtained.
\end{abstract}

Keywords. Microplastics, Sampling method, freshwater, sea water

\section{Introduction}

Microplastics are sourced from plastic that has been used and then discarded or deliberately thrown into the river. Plastic will be carried away by river currents [18]. Some are stuck on rocks and aquatic plants so that eventually they will decompose and are deposited with sediment at the bottom of the river. There are also those that are consumed or inhaled by water biota so that plastic will enter the food chain. Aquatic biota known to eat microplastics include algae (including microalgae), bacteria, fish, birds, reptiles and mammals [12]. Microplastics are also found in oceans from the north pole [3] to the south pole [2]. Microplastic is toxic because it cannot be broken down in the digestive system of living things. Humans as living things that occupy the top of the food chain are inseparable from the risks and dangers of microplastics.

Research on microplastics has been widely carried out throughout the world. His research topics are also very broad including preventive efforts through controlling plastic waste [20]; microplastic distribution both on land, freshwater and marine waters which include water [13], sediments [10], aquatic biota and their accumulation in the food chain[12]; efforts to degradation of environmentally friendly plastics by using microbes and even legal efforts. Different topics cause the research methods used are also different.

As the progress of science and technology, microplastic research methods also experienced significant progress. At first, microplastic observations were limited to observations of microplastic morphology using a microscope. But now, to achieve high research accuracy, many research methods have been developed using sophisticated

\footnotetext{
*Corresponding author: amnan.haris43@gmail.com
} 
technology. In this journal review, we will focus on explaining microplastic research methods in water and sediments

The purpose of this journal review is to describe various research methods that can be used for microplastic observations, along with their advantages and disadvantages.

The benefits of this journal review are providing information about research methods to readers, especially from researchers, lecturers and students who will take research topics in the field of microplastics, so that the review of this journal can be a consideration related to the research methods to be used.

\section{Method}

The research method used is a literature study. Literature review done by collecting literature either from books or journals related to the sampling method of microplastics.

\section{Discussions}

\subsection{Definition of Microplastic}

Microplastic is a piece of plastic $<5$ [20]. Microplastic sources can be divided into 2: primary sources derived from the use of cosmetics; and secondary sources derived from plastic fragmentation. Based on the morphology, microplastics are divided into four types: pellets, fibers, films and fragments [9].



Fig. 1. Morphological Types of Microplastic Morphology (Fahrenfeld et al., 2019)

Microplastic is formed from the process of plastic degradation by environmental factors which include physical, chemical and biological factors. Physical factors come from nonbiotic symptoms that occur in nature, such as sunlight, temperature, weather, wind and water. Chemical factors come from various chemicals and their accompanying properties such as $\mathrm{pH}$. Biological factors derived from the activity of living things such as microbes, fungi, animals and others. Through the degradation process, the polymer chains in the plastic will turn into monomers, not infrequently new chemical bonds will also form as a by-product of the process [21]

Microplastic research methods in both water and sediment are generally divided into several stages, namely: sampling, purification of samples and identification of samples [1] 


\subsection{Sampling Method}

\subsubsection{Microplastic samples in water}

The first step in the microplastic research method is sampling. But before sampling, it is necessary to determine the water column to be sampled, whether the surface, middle or bottom. It is important to know the dominant microplastic morphology. In water samples, the methods that can be used are nets, filters and pumps. The net used is plankton net, neuston and manta nets [4]. A comparison of the advantages and disadvantages of nets, filters and pumps is presented in the following table:

Table 1. Comparison sampling used net, filter and pump

\begin{tabular}{|c|c|c|}
\hline Comparison & Advantages & Disadvantages \\
\hline $\begin{array}{c}\text { Net } \\
\text { - Neuston and mantanets }\end{array}$ & $\begin{array}{c}\text { Easy to use } \\
\text { - Caccommodate a large } \\
\text { sample volume } \\
\text { - Plankton }\end{array}$ & $\begin{array}{c}\text { Wxpensive equipment, } \\
\text { limited to only } 100 \mu \mathrm{m} \\
\text { need a boat, spend a lot of } \\
\text { time }\end{array}$ \\
\hline Filter & $\begin{array}{c}\text { Does not require special } \\
\text { equipment or a boat } \\
\text { Easily get samples } \\
\text { plankton net makes it easily } \\
\text { clogged }\end{array}$ & $\begin{array}{c}\text { Number of medium } \\
\text { samples } \\
\text { Requires a bucket }\end{array}$ \\
\hline Pump & $\begin{array}{c}\text { The number of samples } \\
\text { can be many, saving } \\
\text { energy }\end{array}$ & $\begin{array}{c}\text { Need to ensure the size of } \\
\text { the sample container with } \\
\text { the size of the boat so that } \\
\text { it is not overloaded }\end{array}$ \\
\hline
\end{tabular}

Research results are usually expressed in total microplastics per unit sample (L-1 of water). If you want further research using SEM-EDX, you can get data types, sizes, shapes and colors from microplastics [6].

There is a difference in salinity between fresh water and seawater. This results in a difference in density in the water column. Freshwater density is $1.00 \mathrm{~g} / \mathrm{cm} 3$ while sea water is $1.03 \mathrm{~g} / \mathrm{cm} 3$. Therefore, it is easier for microplastics to sink / settle to the bottom of fresh water [5].

Basically, microplastic sampling of water must minimize the number of impurities or unwanted objects that are involved. For example organic material or minerals. Therefore, equipment such as a bucket or bucket which is not equipped with a net or filter is not recommended. The samples obtained can be contained in a sample bottle. The more samples the better because it will increase representativeness, making it easier to map the distribution of microplastics [11]. 


\subsubsection{Microplastic Samples in Sediments}

Microplastic distribution of sediments is uneven. Its distribution is highly dependent on environmental factors that influence it such as wind and currents. Sediments can be taken from the tidal area to the deepest seabed which allows samples to be taken. The results of the study are very dependent on the sampling location and the tools used. The location of the sample in the tidal zone allows for dry samples to be taken directly. Whereas for waterbased sampling it is necessary to use a boat and only allow wet samples to be taken. Dry sediment sample apparatus can use a bucket, barrel or container, with a note that components other than sediment must be cleaned. Wet sediment sample equipment can use grab sampler, box corer, and gravity core). Sediment samples taken are usually sediments on the surface with a thickness of $1-5 \mathrm{~cm}$. To increase accuracy, it is necessary to repeat the sampling. Dry sediment samples in the tidal area can be repeated 11 times every $100 \mathrm{~m} \mathrm{[6],}$ whereas in wet samples a sample of $400 \mathrm{~g}$ can be taken with a minimum of 5 times [14]

\subsection{Purification of Samples}

The first step in purifying a sample is by filtration. Filtering is used to separate water from microplastic samples. Sieve hole sizes can vary greatly from 0.3 to $200 \mathrm{~mm}$ [17].

Wet samples need to be dried first. The method of purifying microplastic samples from sediments is to use the floatation method. This float utilizes the difference in microplastic density with sediments. Fluid density is regulated by adding salts such as $\mathrm{NaCl}, \mathrm{NaI}$ and $\mathrm{ZnBr} 2$. Any type of microplastic will eventually float if the density of the liquid media is higher than the density of the substance [19].

Table 2. Separation of polimer types by solutions

\begin{tabular}{|c|c|c|c|c|c|}
\hline Polymer & $\begin{array}{c}\text { Density } \\
\left(\mathrm{g} \mathrm{cm}^{-3}\right)\end{array}$ & $\begin{array}{c}\text { Water } \\
1 \mathrm{~g} \mathrm{~cm}^{-3}\end{array}$ & $\begin{array}{c}\mathrm{NaCl} \\
1.2 \mathrm{~g} \mathrm{~cm}^{-3}\end{array}$ & $\begin{array}{c}\mathrm{NaI} \\
1.6 \mathrm{~g} \mathrm{~cm}^{-3}\end{array}$ & $\begin{array}{c}\mathrm{ZnBr} 2 \\
1.7 \mathrm{~g} \mathrm{~cm}^{-3}\end{array}$ \\
\hline PP & $0.9-0.91$ & + & + & + & + \\
\hline PE & $0.92-0.97$ & + & + & + & + \\
\hline PS & $1.04-1.1$ & - & + & + & + \\
\hline PVC & $1.16-1.58$ & - & \pm & + & + \\
\hline PET & $1.37-1.45$ & - & - & + & + \\
\hline
\end{tabular}

Label: + : separation, \pm : possible separation, - : not separated

For the purification of samples from organic materials can be done by giving liquids with acidic, basic or enzyme atmosphere. Acid solutions that can be used are nitric acid ( $\mathrm{HNO} 3,55 \%)$ at $80 \mathrm{oC}$ to destroy fish body tissue, and hydrochloric acid $(\mathrm{HCl}, 37 \%)$ at $25 \mathrm{oC}$ [14]. Base solution which can be used is $10 \% \mathrm{NaOH}$ or $\mathrm{KOH}$ at $60 \mathrm{oC}$ for 24 hours[5]. Hydrogen peroxide (H2O2, 30-35\%) can also be used to destroy organic matter, even more effectively than $\mathrm{NaOH}$ and $\mathrm{HCl}$ [11]. Enzymes tend to be safer to use. For example the Protease Enzyme combined with $\mathrm{CaCl} 2$ was incubated at 50C for 2 hours, followed by shaking [16]. 


\subsection{Sample Identification}

\subsubsection{Morphological Visualization}

Visual identification of microplastics is the first step before chemical characterization. Through visualization, microplastic morphology or topography can be obtained more clearly. Before being observed, the sample must be dyed first. This is done in order to facilitate the observation process. Dyes that are often used are Rose-Bengal and NileRed[9]. Tools that can be used for observation are light microscopy and SEM. But sometimes there are contaminants that obscure the real microplastic, so it needs to be further investigated for their chemical characteristics [17].

\subsubsection{Chemical Characterization}

Microplastic chemical characterization was carried out using FTIR [5], EDX [8], GC-MS [7], and XRF [6]. Fourier Transform Infrared Spectroscopy (FTIR) functions to determine the functional groups and molecular bonds of chemical compounds in the sample. Energy Dispersive X-ray spectroscopy (EDX) functions to determine the inorganic composition of a sample using X-rays. Gas Chromatography-Mass Spectrometry (GC-MS) is used to test the purity of a particular material, or separate various components from a mixture. X-Ray Fluoresence (XRF) is used to analyze the chemical composition and concentration of the elements contained in a sample by using the spectrometry method

\section{Conclusion}

Microplastic research methods in both water and sediment are generally divided into several stages, namely: sampling, sample purification and sample identification. Samples can come from water or sediment. Purification of the sample was carried out to separate the microplastics from contaminants such as organic matter and minerals. Sample identification is carried out to observe microplastic morphology and chemistry

\section{References}

1. A. Besley, M.G. Vijver, P. Behrens, T. Bosker, A standardized method for sampling and extraction methods for quantifying microplastics in beach sand, Mar. Pollut. Bull. 114 (2017)

2. A. Cincinelli, C. Scopetani, D. Chelazzi, E. Lombardini, T. Martellini, A. Katsoyiannis, M.C. Fossi, S. Corsolini, Microplastics in the surface waters of the Ross Sea (Antarctica): occurrence, distribution and characterization by FTIR, Chemosphere 175 (2017)

3. A. Cozar, E. Martí, C.M. Duarte, J. García-de-Lomas, E. van Sebille, T.J. Ballatore, V.M. Eguíluz, I. Gonzalez-Gordillo, M.L. Pedrotti, F. Echevarría, R. Trouble, X. Irigoien, The Artic ocean as a dead end for floating plastics in the North Atlantic branch of the Termohaline circulation, Sci. Adv. 3 (4) (2017) 
4. A. McCormick, T.J. Hoellein, S.A. Mason, J. Schluep, J.J. Kelly, Microplastics is an abundant and distinct microbial habitat in an urban river, Environ. Sci. Technol. 48 (20) (2014)

5. A.M. Elert, R. Becker, E. Duemichen, P. Eisentraut, J. Falkenhagen, H. Sturm, U. Braun, Comparison of different methods for MP detection: what can we learn from them, and why asking the right question before measurements matter? Environ. Pollut. 231 (2017)

6. A. Turner, In situ elemental characterization of marine microplastics by portable XRF, Mar. Pollut. Bull. 124 (2017)

7. E. Dümichen, P. Eisentraut, C.G. Bannick, A.-K. Barthel, R. Senz, U. Braun, Fast identification of microplastics in complex environmental samples by a thermal degradation method, Chemosphere 174 (2017)

8. E. Fries, J.H. Dekiff, J. Willmeyer, M.T. Nuelle, M. Ebert, D. Remy, Identification of polymer type and additives in marine microplastic particles using pyrolysis-GC/MS and scanning electron microscopy, Environ. Sci. Process. Impacts 15 (2013)

9. Harding, S. Marine Debris: Understanding, Preventing and Mitigating the Significant Adverse Impacts on Marine and Coastal Biodiversity, CBD Technical Series. (2016)

10 J.P.G.L. Frias, J. Gago, V. Otero, P. Sobral, Microplastics in coastal sediments from Southern Portuguese shelf waters, Mar. Environ. Res. 114 (2016)

11. M. Browne, T.S. Galloway, R.C. Thompson, Spatial patterns of plastic debris along Estuarine shorelines, Environ. Sci. Technol. 44 (9) (2010)

12. M. Cole, P. Lindeque, C. Halsband, T.S. Galloway, Microplastics as contaminants in the marine environment: a review, Mar. Pollut. Bull. 62 (2011)

13. M.P. Rodrigues, N. Abrantes, F.J.M. Gonçalves, H. Nogueira, J.C. Marques, A.M.M. Gonçalves, Spatial and temporal distribution of microplastics in water and sediments of freshwater system (Antua River, Portugal), Sci. Total Environ. 633 (2018)

14. MSFD Technical Subgroup on Marine Litter, Guidance on Monitoring of Marine Litter in European Seas. A Guidance Document within the Common Implementation Strategy for the Marine Strategy Framework Directive, European Commission, (2013).

15. Q. Qiu, Z. Tan, J. Wang, J. Peng, M. Li, Z. Zhan, Extraction, enumeration and identification methods for monitoring microplastics in the environment, Estuar. Coast Shelf Sci. 176 (2016)

16. S. Zhang, X. Yang, G. Gertsen, P. Peters, T. Sal anki, V. Geissen, A simple method for the extraction and identification of light density microplastics from soil, Sci. Total Environ. 616 (2018)

17. S. Ziajahromi, P.A. Neale, L. Rintoul, F.D.L. Leusch, Wastewater treatment plants as a pathway for microplastics: Development of a new approach to sample wastewater-based microplastics, Water Res. 112 (2017)

18 T. Mani, A. Haulk, U. Walter, P. Burkhardt-Holm, Microplastics profile along the Rhine river, Sci. Rep. 5 (2015)

19. W.J. Shim, S.H. Hong, S. Eo, Identification methods in microplastic analysis: a review, Anal. Meth. 9 (9) (2017)

20.Zanella, M. et al. Microplastic interactions with freshwater microalgae: Heteroaggregation and changes in plastic density appear strongly dependent on polymer type, 215 (2016)

21. Fachrul, M. F. and Rinanti, A. 'Bioremediasi Pencemar Mikroplastik di Ekosistim Perairan Menggunakan Bakteri Indigenous (Bioremediation of Microplastic Pollutant in Aquatic Ecosystem by Indigenous Bacteria)', Seminar Nasional Kota Berkelanjutan, 1(1) (2018) 